\title{
The Causes of Early Implant Bone Loss: Myth or Science?
}

\author{
Tae-Ju Oh, * Joongkyo Yoon, ${ }^{*}$ Carl E. Misch, ${ }^{\dagger}$ and Hom-Lay Wang*
}

The success of dental implants is highly dependent on integration between the implant and intraoral hard/soft tissue. Initial breakdown of the implant-tissue interface generally begins at the crestal region in successfully osseointegrated endosteal implants, regardless of surgical approaches (submerged or nonsubmerged). Early crestal bone loss is often observed after the first year of function, followed by minimal bone loss ( $\leq 0.2 \mathrm{~mm}$ ) annually thereafter. Six plausible etiologic factors are hypothesized, including surgical trauma, occlusal overload, peri-implantitis, microgap, biologic width, and implant crest module. It is the purpose of this article to review and discuss each factor. Based upon currently available literature, the reformation of biologic width around dental implants, microgap if placed at or below the bone crest, occlusal overload, and implant crest module may be the most likely causes of early implant bone loss. Furthermore, it is important to note that other contributing factors, such as surgical trauma and periimplantitis, may also play a role in the process of early implant bone loss. Future randomized, well-controlled clinical trials comparing the effect of each plausible factor are needed to clarify the causes of early implant bone loss. J Peridontol 2002;73:322-333.

\section{KEY WORDS}

Biologic width; bone loss/etiology; dental implants/complications; dental implants failure; dental occlusion, traumatic; peri-implant diseases.

* Department of Periodontics/Prevention/Geriatrics, University of Michigan School of Dentistry, Ann Arbor, MI.

$\dagger$ Department of Periodontics/Prevention/Geriatrics, University of Michigan School of Dentistry; private practice, Birmingham, MI.
The longevity of dental implants is highly dependent on integration between implant components and oral tissues, including hard and soft tissues. Initial breakdown of the implant-tissue interface generally begins at the crestal region in successfully osseointegrated endosteal implants. ${ }^{1-3}$ In particular, after the first year of function (prosthesis loading), crestal bone loss to or beyond the first thread of titanium screw implants, characterized by "saucerization," is often observed radiographically around certain implant types (Fig. 1). Studies have shown that submerged titanium implants had $0.9 \mathrm{~mm}$ to $1.6 \mathrm{~mm}$ marginal bone loss from the first thread by the end of first year in function, while only $0.05 \mathrm{~mm}$ to $0.13 \mathrm{~mm}$ bone loss occurred after the first year. ${ }^{1,3-5}$ The first report in the literature to quantify the early crestal bone loss was a 15-year retrospective study evaluating implants placed in edentulous jaws. ${ }^{1}$ In this study, Adell et al. reported an average of $1.2 \mathrm{~mm}$ marginal bone loss from the first thread during healing and the first year after loading. In contrast to the bone loss during the first year, there was an average of only $0.1 \mathrm{~mm}$ bone lost annually thereafter. Based on the findings in submerged implants, Albrektsson et al. ${ }^{6}$ and Smith and $Z^{2 a r b}{ }^{7}$ proposed criteria for implant success, including a vertical bone loss less than $0.2 \mathrm{~mm}$ annually following the implant's first year of function. Nonsubmerged implants also have demonstrated early crestal bone loss, with greater bone loss in the maxilla than in the mandible, ranging $0.6 \mathrm{~mm}$ to $1.1 \mathrm{~mm}$, at the first year of function. $2,8,9$

There is a lack of agreement as to why greater bone loss occurred during healing and the first year of implant function than following years. Many possible etiologies of early implant bone loss (from implant placement to 1-year post-loading) including surgical trauma, occlusal overload, peri-implantitis, the presence of microgap, reformation of biologic width, implant crest module, and others have been proposed. The purpose of this paper is to analyze each possible cause of early implant bone loss in an attempt to address this complex problem.

\section{SURGICAL TRAUMA}

Surgical trauma has been regarded as one of the most commonly suspected etiologies proposed for early implant failure. ${ }^{10-12}$ Implants which fail due to 


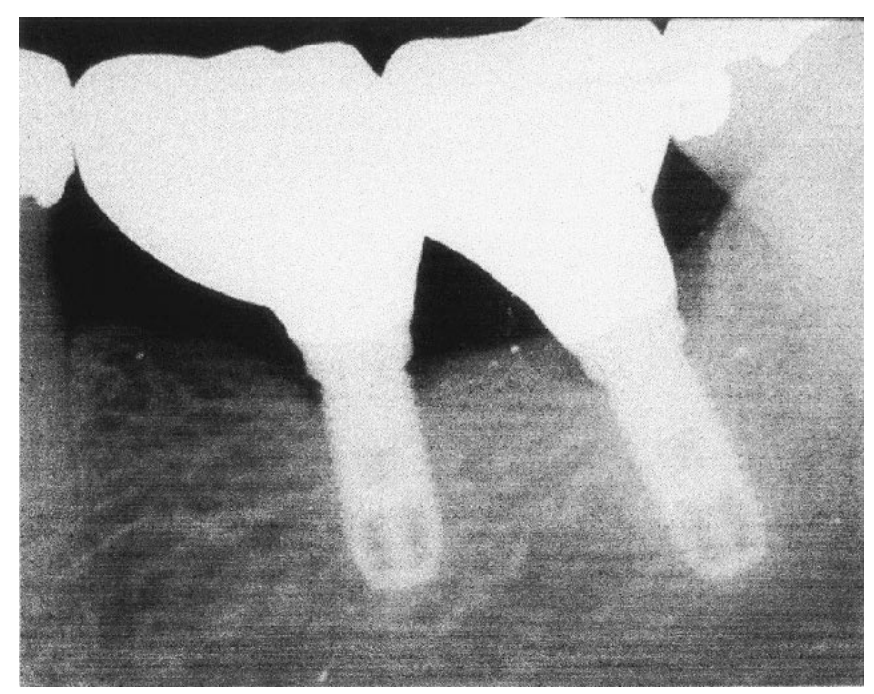

Figure I.

Radiographic evidence of early implant bone loss. The crestal bone loss was noted on both implants to the first fixture thread after I year of function.

surgical trauma are often surrounded by fibrous connective tissues or have an apical extension of the junctional epithelium. ${ }^{13}$ Heat generated at the time of drilling, elevation of the periosteal flap, and excessive pressure at the crestal region during implant placement may contribute to implant bone loss during the healing period.

In 1984, Eriksson and Albrektsson reported that the critical temperature for implant site preparation was $47^{\circ} \mathrm{C}$ for 1 minute or $40^{\circ} \mathrm{C}$ for 7 minutes. ${ }^{14}$ When the bone is overheated, risk of implant failure is significantly increased. Overheating may be generated by excessive pressure at the crestal region during implant surgery. Matthews and Hirsch ${ }^{15}$ demonstrated that temperature elevation was influenced more by the force applied than drill speed. However, it was found that when both drill speed and applied force were increased, no significant increase in temperature was observed due to efficient cutting. ${ }^{15,16}$

The periosteal elevation has been speculated as one of the possible contributing factors for crestal implant bone loss. Wilderman et al. ${ }^{17}$ reported that the mean horizontal bone loss after osseous surgery with periosteal elevation is approximately $0.8 \mathrm{~mm}$, and the reparative potential is highly dependent upon the amount of cancellous bone (not cortical bone) existing underneath the cortical bone. The bone loss, if observed, at stage II implant surgery (implant uncovering surgery in submerged implants) in suc- cessfully osseointegrated implants is generally vertical and has been measured to be between $0.2 \mathrm{~mm}$ and $1.3 \mathrm{~mm} .{ }^{1,18}$ However, the bone loss noted was only around the implant, not the surrounding bone even though during the surgery all the bone was exposed, not just the implant region. Additionally, the pattern of bone loss differs between early implant bone loss and the bone loss after osseous surgery in natural teeth; the early implant bone loss is characterized by "saucerization" rather than horizontal resorption noted after osseous surgery in natural teeth. Therefore, this hypothesis is not generally supported.

In summary, the signs of bone loss from surgical trauma and periosteal reflection are not commonly observed at implant stage II surgery in successfully osseointegrated implants; furthermore, the pattern of bone loss in implants is more likely to be vertical than horizontal. Hence, the hypothesis of the surgical causes of early implant bone loss remains to be determined.

\section{OCCLUSAL OVERLOAD}

Occlusal overload is considered a major cause of implant failure. Research has indicated that occlusal overload often resulted in marginal bone loss or deosseointegration of successfully osseointegrated implants. 1,5,19-25 Unlike natural teeth, osseointegrated implants are ankylosed to surrounding bone without the periodontal ligament which has mechanoreceptors and shock-absorbing function. In addition, the crestal bone around dental implants could be a fulcrum point for lever action when a bending moment is applied, suggesting that implants could be more susceptible to crestal bone loss by mechanical force. Rangert et al., ${ }^{26}$ in a retrospective clinical analysis, described contributing factors associated with increased bending overload in dental implants. These included: prostheses supported by 1 or 2 implants in the posterior region, straight alignment of implants, significant deviation of the implant axis from the line of action, high crown/implant ratio, excessive cantilever length, discrepancy in dimensions between the occlusal table and implant head, and parafunctional habits. The cortical bone is known to be least resistant to shear force, ${ }^{27}$ which is significantly increased by bending overload. Therefore, the above-mentioned factors may result in progressive marginal bone loss or even deosseointegration if the bending overload increases beyond the threshold of bone homeostasis.

Loss of osseointegration by occlusal overload was observed in monkeys by Isidor. ${ }^{24,25}$ Among 5 implants 
placed in each of 4 monkeys, 2 implants received occlusal overload 6 months after implant placement by prostheses causing lateral displacement of the mandible during occlusion. Oral hygiene was employed to the overloaded implants. The remaining 3 implants were not loaded but plaque accumulation was encouraged (ligature placement without oral hygiene). The results demonstrated that 5 out of 8 implants with overload lost osseointegration 4.5 months to 15.5 months after initiation of the occlusal overload, whereas all implants with plaque accumulation remained osseointegrated. Of the 3 implants which did not fail among the implants with occlusal overload, 1 lost approximately one-half of the crestal bone, and the other 2 in the same animal showed the highest bone-to-implant contact and bone density. Isidor ${ }^{24,25}$ stated that the increased bone density in the 2 implants would prevent the implant failure and provide limited amount of crestal bone loss. During 18 months after initiation of overload or plaque accumulation, there was progressive marginal bone loss observed in both groups: $5.5 \mathrm{~mm}$ for the overload group versus $1.8 \mathrm{~mm}$ for the plaque group at 18 months. Even though the bone loss in the overload group was 3 times greater than the bone loss in the plaque group, there was no statistically significant difference between the 2 groups, probably due to the small sample size. The study concluded that occlusal overload can be a causative factor for implant failure, and both occlusal overload and peri-implant infection can result in progressive marginal bone loss. Contradictory to Isidor, ${ }^{24,25}$ Hürzeler et al. ${ }^{28}$ showed histologically that a repetitive mechanical trauma did not influence peri-implant bone loss in healthy or in diseased implant sites up to 16 weeks in monkeys. The difference of the results in these studies may be attributed to the different experimental periods and different levels of forces used to induce occlusal overload.

In a series of the experimental studies in monkeys by Miyata et al., ${ }^{29-31}$ the influence of occlusal overload on peri-implant tissue was histologically investigated. In the first part, they found that peri-implant bone loss was not observed when occlusal overload was applied by a superstructure with an excess occlusal height of $100 \mu \mathrm{m} .{ }^{29}$ On the other hand, in the second report, peri-implant bone destruction was clearly demonstrated by a combination of occlusal overload (provided by an excessive occlusal height of $100 \mu \mathrm{m}$ on a superstructure) and experimental inflammation. ${ }^{30}$ In the last part, ${ }^{31}$ occlusal overload was employed with 3 different excess occlusal heights $(100 \mu \mathrm{m}, 180 \mu \mathrm{m}, 250 \mu \mathrm{m})$ on implant prostheses for 4 weeks, and oral hygiene was performed. Bone destruction was observed in $180 \mu \mathrm{m}$ and $250 \mu \mathrm{m}$ excess occlusal height groups, indicating existence of a critical point of excessive occlusal height on the prostheses for crestal bone loss. From these studies, it can be concluded that peri-implant bone resorption may occur under severe occlusal overload or under co-existence of inflammation and occlusal overload.

The modulus of elasticity is a measure of material stiffness whereas a stress value is expressed as force divided by area. The modulus of elasticity of titanium is approximately 5 times greater than the cortical bone. ${ }^{32}$ According to VonRecum, ${ }^{33}$ when 2 materials of different moduli of elasticity are placed together without intervening material and one is loaded, a stress contour increase is observed where the two materials first come into contact. Photoelastic and 3-dimensional finite element analysis (FEA) studies demonstrated V- or U-shaped stress patterns with greater magnitude near the point of the first contact between implant and photoelastic block, which is similar to the early crestal bone loss phenomenon. ${ }^{34,35}$ Misch claimed that the stresses at the crestal bone may cause microfracture or overload, resulting in early crestal bone loss during the first year of function, and the change in bone strength from loading and mineralization after 1 year alters the stressstrain relationship and reduces the risk of microfracture during the following years. ${ }^{36}$ In addition, he stated that the etiology of early crestal bone loss and early implant failure after loading is primarily from excessive stress transmitted to the immature implant-bone interface. ${ }^{36}$ This suggests that stress reduction might be needed in early stages of bone healing and in poor quality bone. Stress reduction can be achieved by increasing surface area and decreasing forces because stress is force divided by area.

Wiskott and Belser ${ }^{37}$ described a lack of osseointegration attributed to an increased pressure on the osseous bed during implant placement, establishment of a physiologic "biologic width," stress shielding and lack of adequate biomechanical coupling between the load-bearing implant surface and the surrounding bone. Among these causes, they focused on the significance of the relationship between stress and bone homeostasis. Based on the previous study by Frost, ${ }^{38} 5$ types of strain levels interrelated with different load levels in the bone were described: 1) disuse, bone resorption; 2) physiologic load, bone homeostasis; 3) mild overload, bone mass increase; 4) pathologic overload, irreversible bone damage; and 5 ) fracture. The study concluded that adequate strain 
levels, such as bone homeostasis and bone mass increase, are the only requirement for successful integration of load bearing surfaces.

Several authors speculated that "local overload" might contribute to the formation of "saucerization" of crestal bone adjacent to implants. The concept of "microfracture" proposed by Roberts et al. ${ }^{39}$ is often used. The article described that crestal regions around dental implants are high stress bearing areas, and further explained that if the crestal region is overloaded during bone remodeling, "cervical cratering" is created around dental implants. The study also suggests that axially directed occlusion as well as progressive loading are recommended to prevent "microfracture" during the bone remodeling periods.

Progressive loading on dental implants during healing stages was first described by Misch in the1980s to decrease early implant bone loss and early implant failure. Based on the concept, progressive loading needs to be employed to allow the bone to form, remodel, and mature to resist stress without detrimental bone loss by staging application of diet, occlusal contacts, prosthesis design, and occlusal materials. ${ }^{40}$ Misch et al. ${ }^{41}$ evaluated 364 consecutively placed implants in 104 patients where the progressive protocol had been employed. It was reported that a $98.9 \%$ success rate at stage II uncovering surgery was observed, followed by no early loading failures during the first year of function. However, no control group without progressive loading was used in the study, and it was not possible to objectively determine the influence of progressive loading on early crestal bone loss. In another study, a decrease in crestal bone loss was observed in progressively-loaded implants, compared to implants without progressive loading, within a similar healing and loading period; in addition, digital radiographs indicated an increase in bone density in the crestal $40 \%$ of the implant in the progressive loaded crowns. ${ }^{42}$ The study suggests that controlling occlusal load with progressive loading in accordance with bone density may be beneficial to reduce early implant bone loss in healing periods.

Occlusal overload can result in progressive marginal bone loss or even complete loss of osseointegration, and when traumatic occlusion is combined with inflammation, the progression of bone destruction is accelerated. ${ }^{24,25,30}$ However, considerably greater crestal bone loss observed at the first year of function compared to following years may not be clearly explained only by occlusal overload because bone loss resulting from occlusal overload is considered to be progressive rather than a phenomenon limited to the first year after loading. A possibility of the cause for reduced occlusal overload or increased resistance to occlusal overload after the first year of function includes a functional adaptation of the oral musculature, wear of the prosthesis material, and/or an increase in bone density after a certain time period.

In summary, implant bone loss may occur if the stress is excessive (i.e., pathologic overload). Accordingly, the early implant bone loss may be induced by occlusal overload or some types of excessive stress on immature bone-implant interface in the early stage of implants in function. Also, it could explain how the "saucerization" forms up to the first year of function.

\section{PERI-IMPLANTITIS}

Together with occlusal overload, peri-implantitis is one of the two main causative factors for implant failure in later stages. A correlation between plaque accumulation and progressive bone loss around implants has been reported in experimental studies ${ }^{43-45}$ and clinical studies. ${ }^{1,19,46}$ Tonetti and Schmid reported that peri-implant mucositis is a reversible inflammatory lesion confined to peri-implant mucosal tissues without bone loss; on the other hand, peri-implantitis begins with bone loss around dental implants. ${ }^{23}$

As in the case of the natural teeth, peri-implant mucositis and peri-implantitis occur as a result of breaking down host-parasite equilibrium. Clinical features of peri-implantitis were described by Mombelli ${ }^{47}$ as including: 1) radiographic evidence of vertical destruction of the crestal bone; 2 ) formation of a periimplant pocket in association with radiographic bone loss; 3) bleeding after gentle probing, possibly with suppuration; 4) mucosal swelling and redness; and 5) no pain typically. Mombelli et al. ${ }^{48}$ evaluated the microbiota associated with successful or failing implants and suggested that "peri-implantitis" is regarded as a site-specific infection and has microbial features similar to chronic periodontitis. The healthy sites harbored small amounts of bacteria, mainly coccoid cells. On the other hand, microbiota obtained from failing implants consisted of a large proportion of Gram negative anaerobic rods, with black-pigmented Bacteroides and Fusobacterium spp. as well as spirochetes. The microbial features were site-specific rather than host-dependent. Lee et al. ${ }^{49}$ investigated microbiota of successfully osseointegrated dental implants in 43 partially edentulous patients. The results suggested that a history of periodontitis had a greater impact on the peri-implant microbiota than implant loading time. It was also demonstrated that the microbiota on remaining teeth 
significantly influenced the composition of periimplant microbiota.

In an experimental study evaluating the pattern of ligature-induced breakdown of peri-implant and periodontal tissues in beagle dogs, significantly greater tissue destruction was demonstrated clinically, radiographically, and histomorphometrically at implant areas than at tooth sites. ${ }^{43}$ It was also found that significantly fewer vascular structures existed at implant sites compared to periodontal tissues. The difference in collagen fiber direction (parallel to the implant surface and perpendicular to tooth surface) and amount of vascular structure may explain the faster pattern of tissue destruction in peri-implant tissues than periodontal tissues.

Literature has shown that peri-implantitis is similar in nature to periodontitis in that the microbiota of peri-implantitis resemble the microbiota of periodontitis; however, there has been no evidence that peri-implantitis induces crestal bone loss during healing and the first year of function at a faster rate than following years. In fact, the early crestal bone loss may result in an environment that is favorable for anaerobic bacterial growth, thus possibly contributing to more bone destruction in following years. Nonetheless, in the majority of implants the bone loss is dramatically reduced after the first year of prosthesis loading. Therefore, it may not be justified that peri-implantitis is the main causative factor for early implant bone loss.

\section{MICROGAP}

In implant dentistry, there are 2 basic approaches to place endosseous implants, including submerged (2stage) and non-submerged (1-stage) implants. In most 2-stage implant systems, after the abutment is connected, a microgap exists between the implant and abutment at or below the alveolar crest. In nonsubmerged implant designs, the implant itself extends above the alveolar crest level; therefore, such a microgap does not exist at the level of the bone.

Implant countersinking below the bone crest was recommended in the Brannemark surgical protocol ${ }^{50}$ to minimize the risk of implant interface movement during bone remodeling, and to prevent implant exposure during healing. Implant countersinking is also used to accommodate the wider implant platform in Brånemark implants or its clones and to enhance emergence profile for implant prostheses at the expense of the crestal bone. The countersinking performed for the above purposes places the abutmentimplant microgap below the crestal bone.
Quirynen and van Steenberghe ${ }^{51}$ and Persson et al. ${ }^{52}$ found microbial species cultivated from internal surfaces of submerged implants or their restorative component parts. The Quirynen and van Steenberghe ${ }^{51}$ study demonstrated the presence of microorganisms in the inner thread of submerged implant fixtures in 9 subjects. The apical part of 2 abutment screws that had been in place for 3 months were examined by means of differential phase-contrast microscopy. The results showed that all screws harbored a significant quantity of microorganisms, mainly coccoid cells $(86.2 \%)$ and nonmotile rods $(12.3 \%)$. Motile organisms $(1.3 \%)$ or spirochetes $(0.1 \%)$ were only sporadically registered. The study implied that a microbial leakage from the microgap between the abutment/fixture interface in submerged implants is the most probable origin for this contamination. However, the possibility of microbial contamination through microgap between the abutment and fixture in submerged implants is related to development of periimplantitis, and its consequence is not limited to the first year after loading.

Berglundh et al. ${ }^{53}$ and Lindhe et al. ${ }^{43}$ also evaluated the microgap of the Brånemark 2-stage implant and found inflamed connective tissue existed $0.5 \mathrm{~mm}$ above and below the abutment-implant connection, which resulted in $0.5 \mathrm{~mm}$ bone loss within 2 weeks after the abutment was connected to the implant.

The influence of the microgap on the peri-implant tissue formation during healing was studied radiographically in dogs by Hermann et al. ${ }^{54}$ Six different types of implant design were used, 2 types of 1part implants and 4 types of 2 -part implants. The 1 -stage approach (non-submerged) was used for the 1 -part implant types and 1 of the 2-part implant types; a 2-stage approach (submerged) was employed on the remaining implant types. Abutment connection was carried out 3 months after implant placement on the implants previously submerged. After 3 months of additional healing, all animals were sacrificed for histologic analysis. Radiographic evaluation included the distance between the top of the implant/abutment and the most coronal bone-toimplant contact using standardized radiographs taken monthly and bone density changes using computerassisted densitometric image analysis (CADIA). The results indicated that in 1-part, non-submerged implants, the crestal bone levels followed at all time points the rough/smooth implant interface; on the other hand, for all 2-part implants, the crestal bone levels appeared dependent on the location of the microgap, approximately $2 \mathrm{~mm}$ below the microgap. 
In addition, CADIA values for all submerged implants were decreased in the most coronal areas, but increased at the new bone level after abutment connection. This study first demonstrated that the microgap between implant/abutment has a direct effect on crestal bone loss independent of surgery approaches, submerged or non-submerged. The study also suggested that epithelial proliferation to establish a biologic width could be responsible for the crestal bone loss found about $2 \mathrm{~mm}$ below the microgap. Later, the radiographic findings were further supported by a histometric analysis performed by the same group. ${ }^{55}$

Even though a microgap does not exist in nonsubmerged implants, crestal bone loss during the first year of function in non-submerged implants has been reported, being equivalent or slightly less than submerged implants. ${ }^{2,8}$ However, stable alveolar bone crest levels from 1 year up to 8 years after implant placement were reported in non-submerged implants. ${ }^{56}$ From the literature review, it can be speculated that although microgap may not be considered as the only cause of early implant bone loss, it might cause implant crestal bone loss during the healing phase if it is placed at or below the bony crest.

\section{BIOLOGIC WIDTH (BIOLOGIC SEAL)}

In natural teeth, the dentogingival junction consists of 3 components: the gingival sulcus, the epithelial attachment, and the connective tissue attachment. The dimensions of the dentogingival junction were studied in human skulls by Gargiulo et al. ${ }^{57}$ and Vacek et al. ${ }^{58}$ Gargiulo et al. ${ }^{57}$ reported that the average value of sulcus depth was $0.69 \mathrm{~mm}$, and the average values for the epithelial attachment and connective tissue attachment were $0.97 \mathrm{~mm}$ and 1.07 $\mathrm{mm}$, respectively. The biologic width included the latter 2, the epithelial attachment and connective tissue attachment, which was $2.04 \mathrm{~mm}$. The values found in Vacek et al. ${ }^{58}$ corresponded to Gargiulo et al.'s findings, ${ }^{57}$ which were $1.14 \mathrm{~mm}$ for epithelial attachment and $0.77 \mathrm{~mm}$ for connective tissue attachment. Both studies concluded that the most consistent value between individuals was the dimension of the connective tissue attachment.

Likewise, around dental implants, the epithelial attachment (or zone) and connective tissue attachment (or zone) exist (Fig. 2), comprising the biologic seal around dental implants that acts as a barrier against bacterial invasion and food debris ingress into the implant-tissue interface. ${ }^{59}$ The epithelial attachment in both implant and natural tooth is composed of hemidesmosome and basal lamina, whereas col-

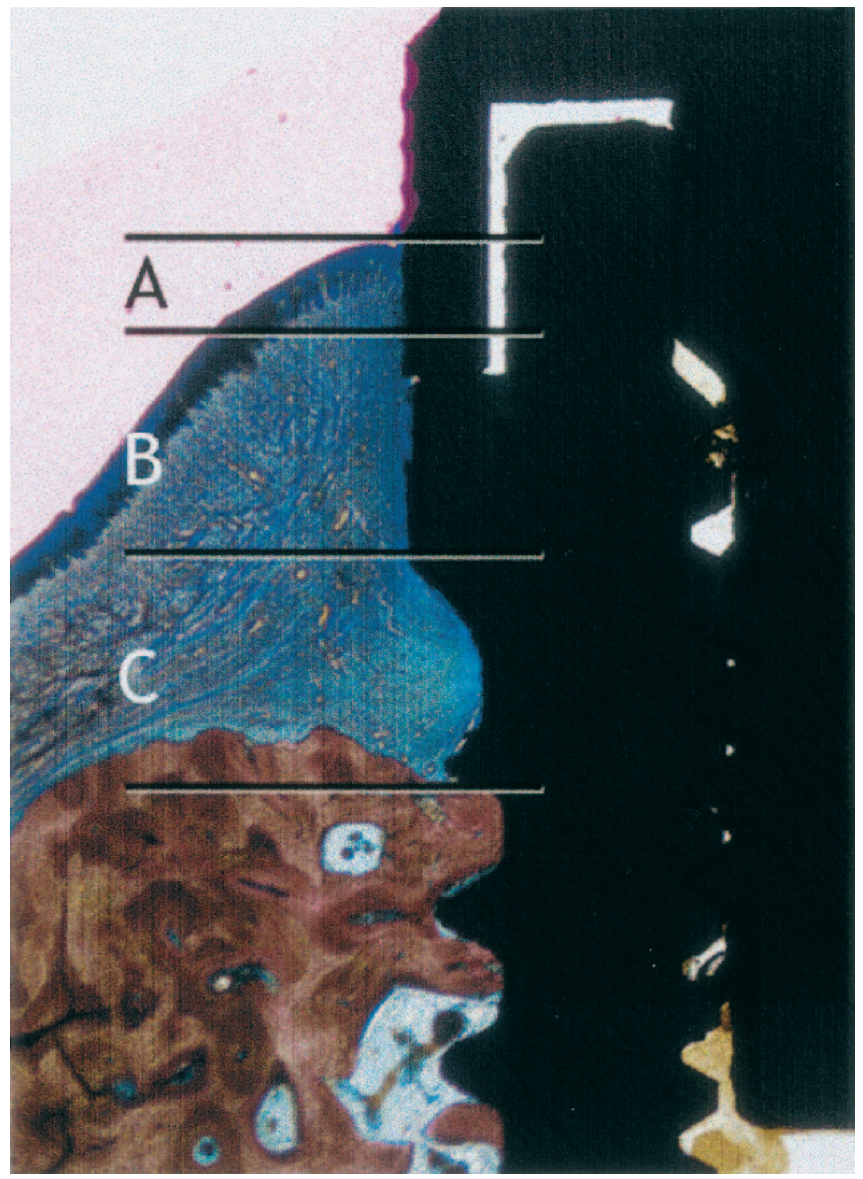

Figure 2.

Histologic illustration of reformation of biologic width. Biologic width, including sulcus depth (A), epithelial attachment, (B) and connective tissue attachment $(\boldsymbol{C})$, has been established around the titaniumthreaded implant 4 months post-implantation (canine model).

lagen fiber direction in the connective tissue attachment is different, being parallel to implant surfaces and perpendicular to natural teeth. ${ }^{60-62}$ Table 1 describes differences noted between implant and tooth.

Cochran et al. ${ }^{68}$ performed a study on loaded and unloaded non-submerged titanium implants and found that the dimensions of the implant/gingival junction remained constant over time up to 12 months after loading. The dimensions were comparable to the dentogingival tissues as described by Gargiulo et al. ${ }^{57}$ After 12 months of loading, the values were $0.16 \mathrm{~mm}$ for the sulcus depth, $1.88 \mathrm{~mm}$ for the junctional epithelium, and $1.05 \mathrm{~mm}$ for the connective tissue attachment. The biologic width reported in the study was $3.08 \mathrm{~mm}$, including the sulcus depth, epithelial 
Table I.

\section{Comparison Between Tooth and Implant}

\begin{tabular}{|c|c|c|}
\hline & Tooth & Implant \\
\hline Connection & $\begin{array}{l}\text { Cementum, bone, } \\
\text { periodontal ligament }\end{array}$ & $\begin{array}{l}\text { Osseointegration, } 63 \\
\text { functional ankylosis } 64\end{array}$ \\
\hline Junctional epithelium ${ }^{60-62}$ & $\begin{array}{l}\text { Hemidesmosomes and } \\
\text { basal lamina (lamina lucida, } \\
\text { lamina densa zones) }\end{array}$ & $\begin{array}{l}\text { Hemidesmosomes and basal } \\
\text { lamina (lamina lucida, lamina } \\
\text { densa, and a sublamina lucida } \\
\text { zones) }\end{array}$ \\
\hline Connective tissue ${ }^{60-62}$ & Perpendicular fibers & Parallel fibers \\
\hline Vascularity 43 & More & Less \\
\hline Probing depth & $\leq 3 \mathrm{~mm}$ in health 65 & $\begin{array}{l}2.5 \mathrm{~mm} \text { to } 4.0 \mathrm{~mm} \\
\text { (dependent on soft tissue depth) }{ }^{1-2}\end{array}$ \\
\hline Bleeding on probing & More reliable 66 & Less reliable ${ }^{67}$ \\
\hline
\end{tabular}

\section{CREST MODULE}
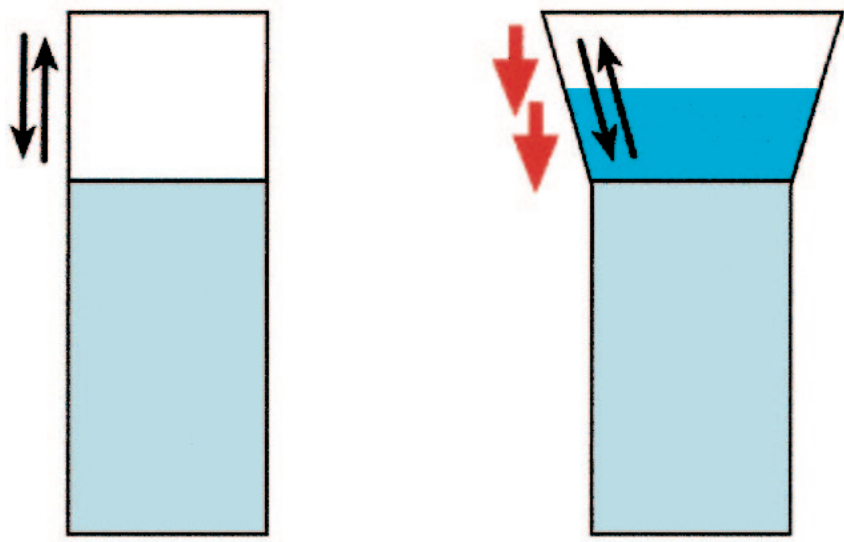

Figure 3.

The crest module design can transmit different types of force to bone. A polished collar as well as a straight crest module design transmits shear $(\uparrow \downarrow)$ force. A rough surface on an angled collar may transmit some compressive ( $Ъ$ ) force to bone.

attachment, and connective tissue attachment. Later, Hermann et al. ${ }^{69}$ histometrically evaluated the dimensional change of the biologic width around non-submerged implants. They observed that each dimension of the sulcus depth, epithelial attachment, and connective tissue attachment changed over time, but within the overall biologic width dimension. The dimensions of the biologic width around submerged implants have also been reported. ${ }^{53,70,71}$ Table 2 lists biologic width studies associated with the natural tooth and dental implant.

Berglundh and Lindhe ${ }^{70}$ studied the dimension of peri-implant mucosa in a beagle dog model. Prior to abutment connection, the ridge mucosa of the test side was surgically made $\leq 2 \mathrm{~mm}$, while the contralateral side (control) remained intact $(>2 \mathrm{~mm}$ ). Following 6 months of plaque control, animals were sacrificed for microscopic observation. The results illustrated that wound healing in the test sites consistently included bone resorption in order to establish about $3 \mathrm{~mm}$ of implant/soft tissue interface (biologic seal). Furthermore, Hämmerle et al. ${ }^{72}$ studied the effect of subcrestal placement of the polished surface of non-submerged implants on marginal soft and hard tissues in 11 patients. At test sites, the apical border of the polished surface was placed about $1 \mathrm{~mm}$ below the alveolar crest, while the junction between rough and polished surface was located at the crest in control sites. After 1 year of function, the average crestal bone loss was $2.26 \mathrm{~mm}$ in the test group and $1.02 \mathrm{~mm}$ in the control group. The study suggested that during the first year of function, the biologic seal was established $1 \mathrm{~mm}$ apical of the rough implant portion at the expense of the crestal bone independent of an initially increased countersink depth.

In a study comparing healed tissues in submerged and non-submerged unloaded dental implants in dogs, it was found that apical extension of epithelial attachment in submerged implants was located below the microgap and significantly greater than that in non-submerged implants. ${ }^{73}$ It was speculated that the greater apical extension of epithelial attachment in submerged implants might have been due to microbial leakage from the microgap after abutment connection at stage II surgery. However, there was no significant difference between the 2 groups in the distance between implant top and first bone-implant contact $(2.92 \mathrm{~mm}$ in submerged versus $2.95 \mathrm{~mm}$ in non-submerged implants). ${ }^{73}$ The study hypothesized that the extent of epithelial downgrowth was not related to the amount of bone resorption occurring after surgery, and that connective tissue appeared to fill that space. Wallace ${ }^{74}$ emphasized the significance of biologic width in dental implants and stated "The 
Table 2.

\section{Studies Regarding the Biologic Width Around Natural Teeth or Dental Implants}

\begin{tabular}{|c|c|c|c|c|c|}
\hline & & & \multicolumn{3}{|c|}{ Dental Implants } \\
\hline & \multicolumn{2}{|c|}{ Natural Teeth } & Non-Submerged & \multicolumn{2}{|c|}{ Submerged } \\
\hline & $\begin{array}{l}\text { Gargiulo et al. }{ }^{57} \\
30 \text { human skulls }\end{array}$ & $\begin{array}{l}\text { Vacek et al. }{ }^{58} \\
10 \text { human skulls }\end{array}$ & $\begin{array}{l}\text { Cochran } \\
\text { et al. } .^{68}\end{array}$ & $\begin{array}{l}\text { Berglundh } \\
\text { et al. } .^{53}\end{array}$ & $\begin{array}{l}\text { Abrahamsson } \\
\text { et al. }{ }^{71}\end{array}$ \\
\hline Sulcus depth (SD) & $0.69 \mathrm{~mm}$ & $1.34 \mathrm{~mm}$ & $0.16 \mathrm{~mm}$ & $2.14 \mathrm{~mm}$ & $2.14 \mathrm{~mm}$ \\
\hline Junctional epithelium (JE) & $0.97 \mathrm{~mm}$ & $1.14 \mathrm{~mm}$ & $1.88 \mathrm{~mm}$ & & \\
\hline $\begin{array}{l}\text { Connective tissue } \\
\text { attachment (CT) }\end{array}$ & $1.07 \mathrm{~mm}$ & $0.77 \mathrm{~mm}$ & $1.05 \mathrm{~mm}$ & 1.66 mm & 1.28 mm \\
\hline Biologic width & $\begin{array}{l}2.04 \mathrm{~mm} \\
(\mathrm{JE}+\mathrm{CT})\end{array}$ & $\begin{array}{l}1.91 \mathrm{~mm} \\
(\mathrm{~J}+\mathrm{CT})\end{array}$ & $\begin{array}{c}3.08 \mathrm{~mm} \\
(\mathrm{SD}+\mathrm{E}+\mathrm{CT})\end{array}$ & $\begin{array}{c}3.80 \mathrm{~mm} \\
(\mathrm{SD}+\mathrm{J}+\mathrm{CT})\end{array}$ & $\begin{array}{c}3.42 \mathrm{~mm} \\
(\mathrm{SD}+\mathrm{JE}+\mathrm{CT})\end{array}$ \\
\hline
\end{tabular}

fact that the ultimate location of the epithelial attachment, following phase two surgery, will be on the implant body is of clinical significance to the implant surgeon since it will in part determine the amount of early post-surgical bone loss."

Based upon these findings, it is apparent that early implant bone loss, in part, is from the processes of establishing the biologic width. The amount of bone loss and location of the biologic width may be associated with thickness of soft tissue around implants, location of the junction between rough and polished surfaces in non-submerged implants, and location of the microgap in submerged implants. However, the reformation of the biologic width may not solely satisfy the causes of early crestal bone loss. As demonstrated in the Weber et al. study, ${ }^{8}$ the maxillary arch had more bone loss than the mandibular arch, which might have been attributed to lower bone density in the maxilla compared to the mandible. Yet, the biologic width should be similar in both arches.

\section{CREST MODULE CONSIDERATIONS}

The crest module of an implant body is defined as the transosteal region of the implant and serves as the region which receives the crestal stresses to the implant after loading. ${ }^{75}$ This region of the implant is often not designed for load bearing, instead is usually designed to minimize plaque accumulation, and acts as a transition zone to the load-bearing structure of the implant body in submerged implants. ${ }^{75}$ With regard to the concept of preventing plaque accumulation, two problems may be observed. First, since toothbrush bristles cannot enter a sulcus on a routine basis more than $1 \mathrm{~mm},{ }^{76}$ and the tissue height above the implant body in submerged implants is usually 2.5 $\mathrm{mm}$ or more, the implant crest module does not provide an environment favorable for hygiene to remove plaque. Second, a smooth crest module may actually contribute to the crestal bone loss. Cortical bone is strongest to compressive loads, $30 \%$ weaker to tensile forces, and $65 \%$ weaker to shear forces compared to compressive forces. ${ }^{77}$ Misch and Bidez claimed that a smooth, parallel-sided crest module may result in shear stresses in this region, and that an angled crest module of more than 20 degrees with a surface texture that increases bone contact might impose a slight beneficial compressive and tensile component to the contiguous bone and decrease the risk of bone loss (Fig. 3). ${ }^{75}$ Significant loss of crestal bone has been reported for implants with 3-mm long, machined (smooth) coronal regions. ${ }^{78}$ It can be speculated that this bone loss may be attributed to the lack of effective mechanical loading between the machined coronal region of the implant and the surrounding bone.

It has been clinically observed that bone is often lost to or below the first thread in some types of submerged implants after loading. 1,3-5,78 Bone grows above the threads during healing as often demonstrated at stage II surgery, but after prosthesis loading, the bone loss down to the first thread is often noted after first year of prosthesis loading. ${ }^{1,3,78}$ Yet, in many submerged implant systems, the distance between the implant platform and the first thread varies, ranging from 1 to $3 \mathrm{~mm}$ (e.g., $1.2 \mathrm{~mm}$ in the Brånemark system and $3 \mathrm{~mm}$ in many screw-vent implant systems). Therefore, the bone loss is probably not related to a specific anatomic length, but 
may be in part related to crest module design. Also, it can be hypothesized that the bone loss may slow down at the first thread because the first thread changes the shear force of the crest module to a component of compressive force to which bone is the most resistant.

The beneficial effect of rough surfaces in the implant crest region in the reduction of crestal bone loss was also demonstrated by the previously presented report by Hermann et al., ${ }^{69}$ which compared 2 different 1-part implant bodies. The first implant had the rough/smooth region placed at the bone crest at surgery, while the other placed the rough/smooth region $1.5 \mathrm{~mm}$ below the bone. After 6 months the bone level remained at the original height of the first implant, while bone loss of $1.5 \mathrm{~mm}$ occurred on the second implant, which corresponded to the rough/ smooth region. The study suggests that the bone loss found in the second implant might have been attributed to reformation of biologic width at the expense of crestal bone, which was related to the implant crest module design. Norton ${ }^{79}$ radiographically evaluated 33 single tooth implants for up to 4 years and reported considerably smaller amounts of crestal bone loss, $0.32 \mathrm{~mm}$ mesially and $0.34 \mathrm{~mm}$ distally. The study postulated that the significantly low degree of crestal bone loss resulted from a modification of the surface structure, both at the macroscopic (microthreaded crest module) and microscopic level (rough surfaces: grit blasted with $\mathrm{TiO}_{2}$ particles), as well as an altered implant-abutment interface design (internal conical interface). Further research in this area is needed to clarify the relationship between implant crest module designs and early implant bone loss.

\section{CONCLUSION}

Early implant crestal bone loss during healing and the first year of function, often greater than bone loss occurring at following years, is generally observed regardless of implant types. Possible causative factors for early implant bone loss include surgical trauma, occlusal overload, peri-implantitis, microgap, biologic width, implant crest module, and others. As demonstrated in photoelastic and finite element analysis studies, stress is concentrated around the crestal region when two materials with different moduli of elasticity are placed together. If some type of excessive stress (pathologic overload) is present at the crestal region after prosthesis loading, implant bone loss begins at this region. This may partly explain why saucerization patterns of marginal bone loss are noted in some types of implants after the first year of function. It has been observed that bone density may also affect the amount of early implant bone loss, and implants with progressive loading in accordance with bone density levels, although hypothetical, may provide less bone loss compared to implants with non-staged loading. In addition, the reformation of biologic width around dental implants can contribute to the early implant bone loss. This process starts immediately after stage II surgery in submerged implants and after implant placement in non-submerged implants. The dimension and position of the biologic width which are related to the degree of early implant bone loss during surgical healing phase may be determined by the location of the microgap if present, or implant crest module designs such as surface textures, implant-abutment interface designs in 2-part implants, and the location of a junction between rough and polished surfaces in nonsubmerged implants. The biologic width inevitably occurs following biomechanisms regardless of implant type, but may not be considered a sole factor associated with early implant bone loss since different levels of early implants bone loss have been reported in the literature depending on implant types. Therefore, it would appear that among all possible contributing factors, reformation of biologic width, occlusal overload, microgap and implant crest module are the most likely contributing causes for the early implant bone loss phenomenon. However, early implant bone loss may also result from or depend on surgical trauma, peri-implantitis, and others.

There has been little evidence on the mechanism of early implant bone loss, lacking studies comparing possible causative factors of early implant bone loss. Therefore, randomized well-controlled clinical trials are needed to determine the true mechanism of early implant bone loss.

\section{ACKNOWLEDGMENT}

This article was partially supported by the University of Michigan, Periodontal Graduate Student Research Fund.

\section{REFERENCES}

1. Adell R, Lekholm U, Rockler B, Brånemark P-I. A 15year study of osseointegrated implants in the treatment of the edentulous jaw. Int J Oral Surg 1981;10:387416.

2. Buser D, Weber HP, Lang NP. Tissue integration of nonsubmerged implants. 1-year results of a prospective study with 100 ITI hollow-cylinder and hollow-screw implants. Clin Oral Implant Res 1990;1:33-40.

3. Jemt T, Lekholm U, Gröndahl K. A 3-year follow up study of early single implant restoration ad modum 
Brånemark. Int J Periodontics Restorative Dent 1990;10: 341-349.

4. Adell R, Lekholm U, Rockler B, et al. Marginal tissue reactions at osseointegrated titanium fixtures. (I) A 3year longitudinal prospective study. Int J Oral Maxillofac Surg 1986;15:39-52.

5. Cox JF, Zarb GA. The longitudinal clinical efficacy of osseintegrated dental implants: A 3-year report. Int $J$ Oral Maxillofac Implants 1987;2:91-100.

6. Albreksson T, Zarb G, Worthington P, Eriksson AR. The long-term efficacy of currently used dental implants: A review and proposed criteria of success. Int J Oral Maxillofac Implants 1986;1:11-25.

7. Smith D, Zarb G. Criteria for success of osseointegrated endosseous implants. J Prosthet Dent 1989;62:567572.

8. Weber HP, Buser D, Fiorellini JP, Williams RC. Radiographic evaluation of crestal bone levels adjacent to nonsubmerged titanium implants. Clin Oral Implant Res 1992;3:181-188.

9. Brägger U, Hafeli U, Huber B, Hämmerle CH, Lang NP. Evaluation of postsurgical crestal bone levels adjacent to non-submerged dental impants. Clin Oral Implants Res 1998;9:218-224.

10. Brånemark P-I, Adell R, Breine U, Hansson BD, Lindström J, Ohlsson A. Intra-osseous anchorage of dental prostheses. Scand J Plast Reconstr Surg 1969;3:81100.

11. Albreksson T. Bone tissue response. In: Brånemark P-I, Zarb GA, Albreksson T, eds. Tissue-Integrated Protheses. Chicago: Quintessence Publishing Co.; 1985:129-143.

12. Esposito M, Hirsch JM, Lekholm U, Thomsen P. Biological factors contributing to failures of osseointegrated oral implants. (II). Etiopathogenesis. Eur J Oral Sci 1998;106:721-764.

13. Piattelli A, Scarano A, Piattelli M. Microscopical aspects of failure in osseointegrated dental implants: a report of five cases. Biomaterials 1996;17:1235-1241.

14. Eriksson RA, Albrektsson T. The effect of heat on bone regeneration. J Oral Maxillofac Surg 1984;42:701-711.

15. Matthews L, Hirsch C. Temperatures measured in human cortical bone when drilling. J Bone Joint Surg 1972;54:297-308.

16. Brisman DL. The effect of speed, pressure, and time on bone temperature during the drilling of implant sites. Int J Oral Masillofac Implant 1996;11:35-37

17. Wilderman MN, Wentz FM, Orban BJ. Histogenesis of repair after osseous surgery. J Periodontol 1970;41: 551-565.

18. Misch CE, Dietsh-Misch F, Hoar J, Beck G, Hazen R, Misch CM. A bone quality-based implant system: first year of prosthetic loading. J Oral Implantol 1999;25: 185-197.

19. Lindquist LW, Rockler B, Carlsson GE. Bone resorption around fixtures in edentulous patients treated with mandibular fixed tissue-integrated prostheses. J Prosthet Dent 1988;59:59-63.

20. Block MS, Kent JN. Factors associated with soft- and hard-tissue compromise of endosseous implants. J Oral Maxillofac Surg 1990;48:1153-1160.

21. Sanz M, Alandez J, Lazaro P, Calvo JL, Quirynen M, van Steenberghe D. Histo-pathologic characteristics of peri-implant soft tissues in Brånemark implants with 2 distinct clinical and radiological patterns. Clin Oral Implant Res 1991;2:128-134.

22. Quirynen M, Naert I, van Steenberghe D. Fixture design and overload influence marginal bone loss and fixture success in the Brånemark system. Clin Oral Implant Res 1992;3:104-111.

23. Tonetti MS, Schmid J. Pathogenesis of implant failures. Periodontol 2000 1994;4:127-138.

24. Isidor F. Loss of osseointegration caused by occlusal load of oral implants. A clinical and radiographic study in monkeys. Clin Oral Implant Res 1996;7:143-152.

25. Isidor F. Histological evaluation of peri-implant bone at implants subjected to occlusal overload or plaque accumulation. Clin Oral Implant Res 1997;8:1-9.

26. Rangert B, Krogh P, Langer B, Van Roekel N. Bending overload and implant fracture: A retrospective clinical analysis. Int J Oral Maxillofac Implants 1995;10:326334.

27. Reilly DT, Burstein AH. The elastic and ultimate properties of compact bone tissue. J Biomech 1975;8:393405.

28. Hürzeler MB, Quinones CR, Kohal RJ, et al. Changes in peri-implant tissue subjected to orthodontic forces and ligature breakdown in monkeys. J Periodontol 1998;69:396-404.

29. Miyata T, Kobayashi Y, Araki H, Motomura Y, Shin K. The influence of controlled occlusal overload on periimplant tissue: A histologic study in monkeys. Int $J$ Oral Maxillofac Implants 1998;13:677-683.

30. Miyata T, Kobayashi Y, Araki H, Shin K, Motomura Y. An experimental study of occlusal trauma to osseointegrated implant: Part 2. J Jpn Soc Periodont 1997; 39:234-241.

31. Miyata T, Kobayashi Y, Araki H, Ohto T, Shin K. The influence of controlled occlusal overload on periimplant tissue. Part 3: A histologic study in monkeys. Int J Oral Maxillofac Implants 2000;15:425-431.

32. Misch CE. Dental evaluation: Factors of stress. In: Misch CE, ed. Contemporary Implant Dentistry, 2nd ed. St. Louis: Mosby; 1999:119-134.

33. VonRecum A, editor. Handbook of Biomaterial Evaluation. New York: Macmillan Publishing Co.; 1986.

34. Bidez M, McLoughlin S, Lemons JE. FEA investigations in plate-form dental implant design. In: Lemon JE, ed. Proceedings of the First World Congress of Biomechanics. San Diego: Society of Biomechanics; 1990.

35. Misch CE. A three-dimensional finite element analysis of two blade implant neck designs. [Thesis]. Pittsburgh, Pennsylvania: University of Pittsburgh; 1989.

36. Misch CE. Dental evaluation: Factors of stress. In: Misch CE, ed. Contemporary Implant Dentistry, 2nd ed. St. Louis: Mosby; 1999:122-123.

37. Wiskott HW, Belser UC. Lack of integration of smooth titanium surfaces: a working hypothesis based on strains generated in the surrounding bone. Clin Oral Implants Res 1999;10:429-444.

38. Frost HM. Wolff's Law and bone's structural adaptations to mechanical usage: an overview for clinicians. Angle Orthod 1994;64:175-188.

39. Roberts WE, Garetto LP, De Castro RA. Remodeling of devitalized bone threatens periosteal margin integrity 
of endosseous titanium implants with threaded or smooth surfaces: Indications for provisional loading and axially directed occlusion. J Indiana Dent Assoc. 1989;68:19-24.

40. Misch CE. Progressive bone loading. In: Misch CE, ed. Contemporary Implant Dentistry, 2nd ed. St. Louis: Mosby; 1999:595-608.

41. Misch CE, Hoar J, Beck G, Hazen R, Misch CM. A bone quality-based implant system: A preliminary report of stage I \& stage II. Implant Dent 1998;7:35-42.

42. Appleton RS, Nummikoski PV, Pigmo MA, Bell FA, Cronin RJ. Peri-implant bone changes in response to progressive osseous loading. J Dent Res 1997;76 (Spec. Issue):412(Abstr. 3191).

43. Lindhe J, Berglundh T, Ericsson I, Liljenberg B, Marinello C. Experimental breakdown of peri-implant and periodontal tissues. A study in the beagle dog. Clin Oral Implant Res 1992;3:9-16.

44. Lang NP, Brägger U, Walther D, Beamer B, Kornman KS. Ligature-induced peri-implant infection in cynomolgus monkeys (I). Clinical and radiographic findings. Clin Oral Implant Res 1993;4:2-11.

45. Schou S, Holmstrup P, Stoltze K, Hjørting-Hansen E, Kornman KS. Ligature-induced marginal inflammation around osseointegrated implants and ankylosed teeth. Clin Oral Implants Res 1993;4:12-22.

46. Becker W, Becker BE, Newman MG, Nyman S. Clinical and microbiologic findings that may contribute to dental implant failure. Int $J$ Oral Maxillofac Implants 1990;5:31-38.

47. Mombelli A. Prevention and therapy of peri-implantitis infections. In: Lang NP, Karring T, Lindhe J, eds. Proceedings of the 3rd European Workshop on Periodontology: Implant Dentistry. Berlin: Quintessence Publishing Co.; 1999:281-303.

48. Mombelli A, Van Oosten MA, Schurch E, Lang NP. The microbiota associated with successful or failing osseointegrated titanium implants. Oral Microbiol Immunol 1987;2:145-151.

49. Lee KH, Maiden MF, Tanner AC, Weber HP. Microbiota of successful osseointegrated dental implants. J Periodontol 1999;70:131-138.

50. Adell R, Lekholm U, Brånemark P-I. Surgical procedures. In: Brånemark P-I, Zarb GA, Albrektsson T, eds. Tissue Integrated Prostheses. Chicago: Quintessence Publishing Co.; 1985:211-240.

51. Quirynen M, van Steenberghe D. Bacterial colonization of the internal part of two-stage implants. An in vivo study. Clin Oral Implant Res 1993;4:158-161.

52. Persson LG, Lekholm U, Leonhardt A, Dahlen G, Lindhe J. Bacterial colonization on internal surfaces of Branemark system implant components. Clin Oral Implant Res 1996;7:90-95.

53. Berglundh T, Lindhe J, Ericsson I, Marinello CP, Liljenberg B, Thomsen P. The soft tissue barrier at implants and teeth. Clin Oral Implants Res 1991;2:8190.

54. Hermann JS, Cochran DL, Nummikoski PV, et al. Crestal bone changes around titanium implants. A radiographic evaluation of unloaded nonsubmerged and submerged implants in the canine mandible. J Periodontol 1997;68:1117-1130.
55. Hermann JS, Buser D, Schenk RK, Cochran DL. Crestal bone changes around titanium implants. A histometric evaluation of unloaded non-submerged and submerged implants in the canine mandible. J Periodontol 2000;71:1412-1424.

56. Buser D, Mericske-Stern R, Dula K, Lang LP. Clinical experience with one-stage, non-submerged dental implants. Adv Dent Res 1999;13:153-161.

57. Gargiulo A, Wentz F, Orban B. Dimensions and relations of the dentogingival junction in humans. J Periodontol 1961;32:261-268.

58. Vacek JS, Gher ME, Assad DA, et al. The dimensions of the human dentogingival junction. Int J Periodontics Restorative Dent 1994;14:154-165.

59. McKinney RV, Steflik DE, Koth DL. The biological response to the single crystal sapphire endosteal dental implant. Scanning electron microscopic observations. J Prosthet Dent 1984;51:372-379.

60. Gould TRL, Westbury L, Brunette DM. Ultrastructural study of the attachment of human gingiva to titanium in vivo. J Prosthet Dent 1984;52:418-420.

61. Hansson HA, Albrektsson T, Brånemark PI. Structural aspects of the interface between tissue and titanium implants. J Prosthet Dent 1983;50:108-113.

62. Listgarten MA, Buser D, Steinemann SG, Donath K, Lang NP, Weber HP. Light and transmission electron microscopy of the intact interfaces between non-submerged titanium-coated epoxy resin implants and bone or gingiva. J Dent Res 1992;71:364-371.

63. Brånemark P-I, Hansson BO, Adell R, et al. Osseointegrated implants in the treatment of the edentulous jaw. Experience from a 10-year period. Scand J Plastic Reconstruct Surg 1977;11:1-132.

64. Schroeder A, Polher O, Sutter F. Tissue reaction to a titanium hollow-cylinder implant with titanium plasmasprayed surface (in German). Schweizerische Monatsschrift für Zahnheilkunde 1976;86:713-727.

65. Ramfjord SP. Indices for prevalence and incidence of periodontal disease. J Periodontol 1959;30:51-59.

66. Lang NP, Adler R, Joss A, Nyman S. Absence of bleeding on probing. An indicator of periodontal stability. $J$ Clin Periodontol 1990;17:714-721.

67. Salcetti JM, Moriarty JD, Cooper LF, et al. The clinical, microbial and host response characteristics of the failing implant. Int J Oral Maxillofac Implants 1997; $12: 32-42$

68. Cochran DL, Hermann JS, Schenk RK, Higginbottom FL, Buser D. Biologic width around titanium implants. A histometric analysis of the implanto-gingival junction around unloaded and loaded nonsubmerged implants in the canine mandible. J Periodontol 1997;68:186-198.

69. Hermann JS, Buser D, Schenk RK, Cochran DL. Biologic width around titanium implants. A physiologically formed and stable dimension over time. Clin Oral Implants Res 2000;11:1-11.

70. Berglundh T, Lindhe J. Dimension of the peri-implant mucosa. Biological width revisited. J Clin Periodontol 1996;23:971-973.

71. Abrahamsson I, Berglundh T, Wennstrom J, Lindhe J. The peri-implant hard and soft tissue characteristics at different implant systems. A comparative study in dogs. Clin Oral Implant Res 1996;7:212-219. 


\section{Review}

72. Hämmerle CHF, Brägger U, Bürgin W, Lang NP. The effect of subcrestal placement of the polished surface of ITI implants on marginal soft and hard tissues. Clin Oral Implant Res 1996;7:111-119.

73. Weber HP, Buser D, Donath K, et al. Comparison of healed tissues adjacent to submerged and non-submerged unloaded titanium dental implants. A histometric study in beagle dogs. Clin Oral Implants Res 1996; 7:11-19.

74. Wallace SS. Significance of the biologic width with respect to root form implants. Dent Implantol Update 1994; 5:25-29.

75. Misch CE, Bidez MW. A scientific rationale for dental implant design. In: Misch CE, ed. Contemporary Implant Dentistry, 2nd ed. St. Louis: Mosby; 1999:329343.

76. Waerhaug J. Effect of tooth brushing on subgingival plaque formation. J Periodontol 1981;52:30-34.

77. Guo EX. Mechanical properties of cortical bone and cancellous bone tissue. In: Cowin SC, ed. Bone Mechanics Handbook. Boca Raton, FL: CRC Press; 2001:10/123.

78. Jung YC, Han CH, Lee KW. A 1 year radiographic evaluation of marginal bone around dental implants. Int $J$ Oral Maxillofac Implants 1996;11:811-818.

79. Norton MR. Marginal bone levels at single tooth implants with a conical fixture design. The influence of surface macro- and microstructure. Clin Oral Implants Res 1998;9:91-99.
Send reprint requests to: Dr. Hom-Lay Wang, Department of Periodontics/Prevention/Geriatrics University of Michigan School of Dentistry 1011 North University Avenue, Ann Arbor, MI 48109-1078. Fax: 734/936-0374. e-mail address: homlay@umich.edu.

Accepted for publication August 20, 2001. 